The 148,963 Australian female students passed 91.7 percent of courses attempted, the 35,039 international females 90.9 percent. The II5,553 Australian male students passed 86.4 percent of courses attempted, the 38,890 international males 86.8 percent. Overall, there was no difference: the 264,516 Australian students passed 89.4 percent of courses attempted, the 73,929 international students 88.8 percent.

\section{Levels of Study}

There were I,908 postgraduate research students in the study. Progress rates for postgraduate research students need to be treated with caution, so these I,908 postgraduate research students, 0.6 percent of the study, were removed from this analysis by level of study.

The 16,839 Australian postgraduate coursework (i.e., not postgraduate research) students passed 94.7 percent of courses attempted, the 246,127 Australian undergraduates 89.3 percent. The 22,592 international postgraduate coursework students passed 92.9 percent of courses attempted, the 50,979 international undergraduates 87 percent. Overall, the 39,43I postgraduate coursework students passed 93.7 percent of courses attempted, the 297,I06 undergraduates 88.9 percent. Simply, postgraduates did better than undergraduates.

The makeup by level of study of the Australian and international cohorts differs: 6 percent of Australian students are postgraduate coursework students, 3I percent of international students are postgraduate coursework students. The international cohort, relatively heavy with postgraduate coursework students, might be expected to outperform the Australian cohort. It is perhaps because of the makeup by levels of study that the research found no difference overall.

\section{The key finding from this study is that at the 22 universities in 2003 international students per- formed as well as Australian students.}

The 246,I27 Australian undergraduates passed 89.3 percent of courses attempted, the 50,979 international undergraduates 87 percent. The I6,839 Australian postgraduate coursework students passed 94.7 percent of courses attempted, the 22,592 international postgraduate coursework students 92.9 percent. Overall, there was no difference: the 262,966 Australian students passed 89.6 percent of courses attempted, the 73,57I international students 88.8 percent.

\section{CONCLUSION}

The key finding from this study is that at the 22 universities in 2003 international students performed as well as Australian students. Two other results are very clear. Female students performed better than male students, and postgraduate coursework students performed better than undergraduate students.

The Australian cohort, relatively heavy with females, might be expected to outperform the international cohort, but the international cohort, relatively heavy with coursework postgraduate students, might be expected to outperform the Australian cohort. Overall, there is no difference: Australian students passed 89.4 percent of courses attempted, international students passed 88.8 percent.

A report of this study, rich in tables and charts, can be downloaded from the International Education Association of Australia website: www.ieaa.org.au/news/.

\section{Pushing Through Bologna Reforms: The Hungarian Case}

\section{Anthony MORGan}

Anthony Morgan is professor of higher education in the Department of Educational Policy and Leadership at the University of Utah. E-mail: anthony.morgan@ed.utah.edu.

Hungary signed off on the Bologna process in 1999 and 1 was admitted to the European Union in May 2004. The Hungarian Parliament passed a new higher education law in June 2005-driven in large measure by the pressures and provisions of the Bologna process. This relatively rapid adoption of change has hit a snag, however, as certain provisions of the new law have been challenged in Hungary's Constitutional Court, which began hearings on the matter this fall. In the meantime, governmental decrees have filled the gap between law and required policies for implementation. Any required revisions in the challenged law will have to be renegotiated through Parliament by a government facing reelection in spring 2006.

This article was based on a series of interviews in August and September 2005 conducted at the Ministry of Education and the University of Szeged as well as on a review of documents in English that have been part of the Bologna process.

\section{Degree Structural Changes}

Hungary has opted to move from its current five-year diploma to a three-year baccalaureate, a two-year master's degree, and the PhD as the highest degree. Government officials see this structure as not only complying with the accords of the Bologna process but also reducing the amount of government subsidies for state-supported students. By contrast, many faculty see a three-year first degree as a threat to the quality of pro- 
grams and inadequate preparation for the labor market. Some faculty interviewed suggested that MA-level training will become the standard, therefore only breaking the current fiveyear diploma into three-year and two-year components. This possibility appears to be precluded, however, by provisions in the new law and decrees that limit the number of governmentfunded enrollments at the master's level to on average onethird (ranging from about Io percent to Ioo percent by disciplinary or professional field) of government-funded baccalaureate places.

\section{UNIVERSITY-COLLEGE TENSIONS}

The right to offer the new first degree (BA) is a hotly contested issue between universities and colleges. Many university faculty believe only university-level institutions have sufficiently high levels of program quality to offer the baccalaureate and have enlisted the support of the Hungarian Accreditation Committee, dominated by university faculty, as their ally. Colleges, on the other hand, were successful in seeking a pro-

\section{Government officials see this structure as not} only complying with the accords of the Bologna process but also reducing the amount of government subsidies for state-supported students.

vision in the new law that the baccalaureate, at least in some disciplines such as business studies and the technical sciences, include one semester of a practicum that they believe colleges are uniquely qualified to provide. Teacher training is another venue where this tension will be played out. Current thinking and draft decrees place teacher certification at the master's level, which ironically could make pedagogical colleges primarily master's level institutions. One way forward is seen in yet further mergers or at least agreements between colleges and universities. This battle over the baccalaureate and master's degree territories has yet to be fought although strategic alliances are being built in both government and accreditation circles.

\section{Credit and Transfer Systems}

A central component of the Bologna process is credit accrual and transfer provisions to promote greater mobility across Europe. The first-level and most commonly implemented form of this principle is the European Credit and Transfer System, which allows students to take courses in other countries that may count for degree programs in their home country. Much more difficult to implement in transition countries are credit and transfer systems that operate within the home university. In most areas of Eastern Europe and the Balkans, university faculties operate somewhat like academic silos where students take virtually all of their classes within their disciplinary faculty. There has been some loosening of this system in Hungary in recent years-for example, pharmacy students at the
University of Szeged now take basic chemistry classes from the Faculty of Science. But there is a long way to go to achieve the extent of efficiencies that many reformers have advocated. Such reforms are impacting job security as well as perceived issues of quality control.

\section{Governing Boards}

Increased European interest in boards as an important component in governance reforms is also being played out in Hungary. In fact this provision of the new law is probably the most keenly contested issue before the Constitutional Court because it allegedly violates the faculty's right to make judgments in scientific matters. The new Hungarian law provides for nine-member boards-five elected by the institutional senate and who cannot be employees of the institution (but who can be academics at other institutions); three members elected by the minister of education; and the rector (who is appointed by this board) as an ex officio member and president of the board. At smaller institutions, the law provides that these boards will have only seven members, two of whom would be chosen by the minister.

This controversial provision for boards in the new law is not a requirement of the Bologna process but comes rather from an increasing sense in government policy circles that a new management structure is needed if institutions of higher education are to function independently and responsibly. As one former deputy state secretary for higher education said, "The rules of the game are changing." In addition, Hungary's neighbor, Austria, has recently implemented a bold change in governance with institutional boards as the centerpiece of redesign.

\section{One way forward is seen in yet further mergers or at least agreements between colleges and uni- versities.}

Boards under the proposed new Hungarian law would have the power to select a rector and the chief financial officer and approve bylaws of university senates, the institutional development plan including new programs, any institutional joint ventures and entrepreneurial initiatives, and all property transactions.

\section{Changing Demographics}

A provision of the July I9, 2005 draft resolution of the European Council states that one of the most important functions of European states is the responsibility for strategic direction of their higher education systems. One of the most significant strategic issues looming for Hungarian as well as other higher education systems in the broader region is a decline in the college-age population. There are currently between I60,000 and I70,000 applicants for first-year study in Hungary's colleges and universities. In six to seven years that 
number will probably decline to IIO,००० or $\mathrm{I} 20,000$. Those interviewed at governmental policy levels were very aware of and concerned about this coming change, while those interviewed at the institutional level seemed much less concerned. Given the implications for funding, admissions standards, and a range of important issues, the lack of institutional attention here was surprising.

What is the probable outcome of this projected decline in traditional college-aged student numbers combined with the push for Bologna reforms? Laszlo Dinya, president of the government's Bologna Committee, outlined what he saw as three possible scenarios. The first is an optimistic scenario where most institutions recognize the changes needed, institute Bologna-type reforms, and adapt successfully to demographic changes. Maygar Balint, minister of education, believes that institutions can adapt by attracting more fee-paying foreign students, engaging in more adult education or lifelong learn-

\section{Maygar Balint, minister of education, believes that institutions can adapt by attracting more fee-paying foreign students,}

ing, and significantly expanding their externally funded research and development, as well as other entrepreneurial activities. The second scenario is a pessimistic one where very few institutions adopt significant reforms or the reforms adopted are largely symbolic in nature. Faced with significant declines in enrollments and funding, a large number of institutions will be either closed or merged. The third scenario is what Professor Dinya sees as the most probable. He sees about one-third of institutions making significant Bologna-type reforms and surviving, even thriving, in the new demographic and governmental funding environment. Another one-third of institutions will either close or merge. The final third will struggle and be less viable institutions with quality problems but probably will survive.

Having worked in Hungary for over I2 years, I saw significant change in that time period. But more change has occurred at the national policy level than the institutional or operational level. During the mid-I990s, national policy change was being driven by the prospect of a World Bank loan with many, perhaps too many, reform strings attached. Since I999, however, the Bologna process has become the primary driving force behind policy changes at the national level. While the legitimacy of this policy impetus is more widely accepted at the institutional level than was the World Bank loan, the specific meaning and implementation of these reforms are encountering long-standing cultural and structural barriers at the faculty level. Here the pace and longer-term outcomes may be quite different. One final example is that prior to the reforms of the late I990s, the city of Szeged had four separate colleges and universities. After the merger reforms there was one consolidated university-the University of Szeged. Yet, as one long- time observer in Szeged said, we now have II fairly independent faculties instead of four institutions. Consolidation in policy and name is clear but perhaps in practice there is more fragmentation and less change that occurs. Bologna holds out the prospect of deeper reform, but changing deeply held cultural norms and disturbing job security takes much longer than policymakers hope or believe.

\section{Australia as an Higher Education Exporter}

\section{Grant Harmon}

Grant Harman is an emeritus professor in the Centre for Higher Education Management and Policy, University of New England, Armidale, NSW 2351 Australia. E-mail: gharman@une.edu.au.

This article discusses some key issues facing Australia today 1 as a leading exporter of international education. In a little over a decade, Australian universities have made impressive developments toward the goal of internationalization of higher education. With government support, they have put considerable efforts into internationalizing curricula and achieving enhanced international research collaboration and benchmarking. But the most dramatic and important developments have been in the expansion of fee-paying international students.

Today Australia is the third-largest commercial exporter of higher education services internationally, coming in rank order after the United States and the United Kingdom. In 2004, Australian public universities enrolled a total of 210,397 international students, constituting 22.6 percent of the country's total higher education enrollments. Private colleges enroll an additional 30,000 international students, while each semester public universities also attract about 8,000 to 10,000 studyabroad and exchange students. Both are not counted in official statistics for public institutions.

The majority of international students study at the undergraduate level, mostly for a three- or four-year bachelor's degree. In 2004, however, 40.2 percent studied for postgraduate qualifications, including 3.4 percent for doctoral degrees. The largest enrollments in 2004 were at Monash University (I7,077), RMIT University (I5,I32), Curtin University (14,319), and Central Queensland University (I0,460).

While export education has developed quickly to become an important component of the higher education sector, a number of issues call for careful monitoring and discussion. Three will be dealt with here: future demand for international student places, "offshore" international enrollments, and quality assurance and risk. 